\section{From Technology to the Need of Technology in High-Tech Society}

\author{
Mihaela BOBOC ${ }^{1}$,
}

Roxana-Ionela

ACHIRICESEI ${ }^{2}$,

Ioan Mircea TURCULET $T^{3}$

${ }^{1} \mathrm{PhD}$ Student, Ştefan cel Mare"

University, Suceava,

mutu.mihaela87@gmail.com.

${ }^{2}$ PhD Student, Ştefan cel Mare"

University, Suceava,

rachiricesei@yahoo.com

${ }^{3} \mathrm{PhD}$ Student, Ştefan cel Mare"

University, Suceava, turculetioan@yahoo.com

\begin{abstract}
Today we are witnessing a level of technological development that has not been seen so far. This state actually forces us, to a certain extent, to admit what Schuurman (2010) claimed, that "the time of the technological society is now!".

Can we allow technology to develop freely, unhindered? Can we let the thirst for knowledge and for evolution to guide our actions in a society where technology has an alarming rhythm of development? Historical evidence shows the opposite (Hiroshima, Chernobyl, etc.). Thereby, enthusiasm declines and criticism and suspicion arise regarding the fact that not all that is technology is good and not all of it can be used for the benefit of humanity, or that technology will exceed the adaptability of humans.

However, at once with the critical thinking, a new field of research begins to emerge, that is technoethics. Technoethics establishes the link between technology and ethics in helping society. The need for such a research field arises with the onset of industrial revolutions when it has been easy to see that technological advances will influence human activity and life, and that greater responsibility is needed in terms of the use of technology. And how can we integrate ethos the moral values and the moral norms in technological activities, if not by establishing a link between ethics and technology, or, more precisely, establishing an ethics (technoethics) that can meet the moral needs of today's society (high-tech).

Therefore, today's technology society needs an ethic, or it needs a "creed" made up of norms and limits (limits of development) which does not allow it to develop to the limit that could subdue humanity to the risk of extinction.
\end{abstract}

Keywords: technology; technological development; ethics; technoethics;

How to cite: Boboc, M., Achiricesei, R.-I., \& Turculet, I.M. (2017). From Technology to the Need of Technology in High-Tech Society. Journal for Ethics in Social Studies, 1(1), 7-14.

https://doi.org/10.18662/jess/02 


\section{Introduction}

Humanity is facing today a great and new challenge. Today there has been achieved a level of technological development that raises questions. How far does the permissiveness of technological development go? Should technology be developed without limits or it needs control? Does today's technological society the need of ethics?

These are a few questions to which this paper attempts to answer. So in the first part are exposed the main technological leaps with major impact on the evolution of the society (the agricultural revolution, the industrial revolution and the informational revolution). Continuous exposure to the major challenges of technological development (catastrophes, wars, riots, risk of self-destruction, the risk of inability to adapt to the accelerated pace of technological development, but also the risk of degreasing the culture by reducing it to a one-dimensional culture).

However, if we talk about the negative effects generated by the evolution and development of technology, then we are talking about reactions and criticism. The main reaction materializes through the emergence of the field of research of the technoethics. That is, an ethics adapted to the needs of a high-tech society. Thus, technoethics appears as a necessity of the technological society. Because with the emergence of this field there are concerns about technology assessment - whether it is good or bad, whether it is used abusively or is used for the benefit of humanity.

\section{Technological development - the main pillar of the evolution of society}

Mankind passes through its development through several stages of development, or, more preferably, through several outstanding historical moments. These historical moments have been caused by the existence of technological revolutions. Because the "technological development has accompanied and influenced the evolution of mankind from its origins, modeling its structure and imprinting it on every age" (Popoveniuc, 2016). Starting with tribal populations (building various tools for food by activities such as hunting, fishing, etc.) and up to the high-tech generation (intensive information), technology has been the main supportive, developmental and evolving support, making it possible to" his thinking, his sense and his will" (Popoveniuc, 2016).

However, although technology has developed continuously, historical moments that have transformed society are few, starting with "the 
very simple idea that the progress of agriculture was the first crossroads in social development, and that the industrial revolution was a second big leap" (Toffler \& Toffler, 1995). So the emergence of agriculture was, as Toffler (1983) argues, "the first turning point in the social development of man" (Toffler, 1983) Because with the emergence of agriculture and later of industry (end of the 17th century), scientific progress and the pace of technological development have accelerated. These have made us today to witness the development of technologies that were unimaginable in the past.

Thus, towards the end of the twentieth century, we seem to witness a new technological revolution generated by knowledge, "knowledge defined as data, information, images, symbols, culture, ideology and values" (Toffler $\&$ Toffler, 1995) or, more precisely, a revolution in information technology. This informational revolution has given rise to new industries ("born of rapid advances made in a series of scientific disciplines...: quantum electronics, information theory, molecular biology, oceanology, nucleonics, ecology and space sciences" (Toffler, 1983) such as: "electronic computers and data processing, aerospace constructions, complex petrochemicals, semiconductors, advanced communications and dozens of others" (Toffler, 1983).

We see, therefore, how society evolves from the first carved stone to high-tech facilities. This high level of technology development is precisely due to technology itself. Because technology generates technology, meaning "the technique feeds on its own substance" (Toffler, 1973) and "no longer based on tradition, but rather on previous technical measures" (Ellul, 1964).

We may therefore agree that technology has its merits in terms of human phylogenesis, but it is not without criticism, dangers and challenges.

\section{Challenges of technological development}

It seems that technological development has not only meant progress and evolution, it also meant change (social, cultural, economic, political, and even paradigm shifts). Such changes did not take place slowly and without repercussions on society and on human values. All these changes involved catastrophes, riots, wars - with their negative effects on society.

Furthermore, the technology has an ambivalent nature. The ambivalence of technology has been accentuated by Jacques Ellul since the 1980's. He believes that "solving problems through technological means immediately generates a multitude of other problems, which makes it impossible to say whether the technology produces good or bad effects; or makes them both" (Ellul, 1980). In the context of a double impact, 
"technological evolution presents, besides the selective advantages, the premises of a possible self-destruction" (Popoveniuc, 2016). That is, the technique "reveals itself at the same time as human power and power of selfdestruction of mankind" (Stiegler, 1998).

Destruction or self-destruction through the uncontrolled development of technology can be possible and due to the alarming rate of change. There is a possibility that man, as a psycho-biological system, does not possess the "weapons" necessary for permanent adaptation and at a rapid pace. There is also the possibility that technology evolution can overcome human evolution by condemning the latter to self-destruction through the inability of social and psychological adaptation.

Also, the current level of technology development has the ability to penetrate and direct the entire culture of humanity. "The end result will be a" technological culture, "so the technology will be in and around and everything will depend on" (Schuurman, 2010). What could lead to a onedimensional culture, to the degradation of human nature and to the dissolution of society! Karl Marx talks about the degradation of human nature with the development of technology since the 1856's.

"Victories of technique seem to be bought at the price of moral degradation. It seems that as humanity submits nature, man becomes the slave of another man or his own misery. Even the pure light of science seems to be shining only on the dark background of ignorance. All our inventions and our progress seem to lead to one result: to equip material forces with spiritual life and to reduce human life to a simple material force" (Marx, 1856).

All of these effects are due to the fact that "no inventor has ever correctly predicted the practical result of his deed" (Spengler, 1966) nor the negative effects on society. However, it is obvious that "developments and changes in the technological system regularly cause disruption of the social system" (Stiegler, 1998), and not only.

However, once technological duplication has been accepted, enthusiasm has gone from some reticence and caution to its development and implementation. Furthermore, it has passed the time of the all-powerful technical thinking that man with the help of technique will master the nature or even the entire universe. Today, one may appreciate that man is no longer considered a "completely autonomous subject, who uses science and technology in a sovereign way to achieve the goals" (Keulartz et al., 2004). Thinking, reflection today, even by an anthropocentric approach, appreciates the environment as valuable. Moreover, it is appreciated that science and 
technology are not always good and that we need to have a more responsible attitude in terms of their applicability.

However, technical thinking has not disappeared, it still dominates society, especially now in an era where technology seems to be a "both individual and collective prosthesis" (Schuurman, 2010) But compared to past eras (such as the beginning of the industrial revolution or even the period of the Enlightenment) today, "ethics also prevails" (Schuurman, 2010). As evidence we have today a new field of research, named technoethics.

\section{The emergence of technoethics}

Tehnoetica evolved during the 1970's-1980's, and was first defined by Mario Bunge to describe the responsibility of technology and scientists. Bunge argues that both the technologist and the engineer must assume greater moral responsibility for their creations. The technologist is morally responsible for his professional actions (Bunge 1975), "the technologist must be not only technical but also morally responsible for everything he designs or executes: his artefacts not only have to be effective, but far from being harmful, they should be beneficial and not only short-term but also long-term" (Bunge, 1975).

About the ethics of technology and the duty of man to his cause is also spoken by Hans Jonas (1979) in the work Towards a philosophy of technology. In Hans Jonas's thinking, the negative effects of technology evolution on the quality of human life and even its conservation are the main arguments behind technology. "In short, surely the human image and possibly the survival of the species (or part of it) is endangered. That would call man's debt to his cause, but also the obligation to deal with threats, bearing, for the first time, the responsibility of the first agent in the threatening disposition of things" (Jonas, 1979).

We can not fail to recall that "efforts to unite ethics and technology began to materialize with the work of Hans Jonas $(1979,1985)$ and recently in the Philosophy of Technology (Mitcham, 1997, 2005)" (Luppicini, 2009).

In his attempt to link technology ethics, Carl Mitcham makes a major contribution to defining the field of Technoetics. His works have as main objective the philosophical inquiry on science, technology and engineering. His study is being guided by the assertion that "virtually all sciences and technologies have ethical and political implications" (Mitcham, 2005).

Also, Valeriu Capcelea speaks about the need for a new field of research in the context of technological development. However, the main 
reason for this is to keep ethics behind technology. Thus, the author claims that, "the catastrophic retreat behind in the elaboration of the ethical adjustment to the consequences of the scientific-technical progress, the adaptation of man and humanity to technology and technologies created the necessity for the emergence, establishment and existence of another ethics, namely the Technoetics, in particular, the problems generated by the interactions between man, the technique and the technologies he created (Capcelea, 2014).

According to Luppicini (2010), the role of Tehnoetics is:

- to focus on the ethical use of technology;

- not to allow abusive use of technology;

- and to develop principles to guide new technological advances, but especially the use of technologies for the benefit of humanity (Luppicini, 2010).

Thus, technoetics offers the opportunity to bring philosophical (ethical) study into the real world.

Also, technoetics offers new opportunities to overcome certain crisis situations and through the fact that it unites scientists from diverse fields. The main areas are: philosophy, social sciences and scientific and technological studies (http://research.omicsgroup.org/index.php/Technoethics).

\section{Conclusions}

It is increasingly evident that technology is the main pillar on which society's evolution is based. History has shown that technological revolutions can be considered evolutionary leaps. However, the development of technology can not be left to develop unbridled and uncritical. Because history has shown us that technology is not always for the benefit of humanity. And if it would not be for the benefit of humanity then it is not desirable, because it would show an immoral purpose.

So, we note that technological development implied not only evolution but also catastrophes, riots, wars - with their negative effects on society. Moreover, the alarming rhythm of technology development can lead to man's inability to adapt. Also, in the context of accelerated technology development, there is a risk of reducing the entire culture of humanity to a one-dimensional culture which will lead to the degradation of human culture.

So, in a society where technology is developing with an alarming speed, and where the negative effects are directly proportional to the pace of development, there is a need for a balance. We can consider that establishing 
a balance can be achieved with the help of an ethics tailored to the new society, an ethics that sets the right principles for a technological society.

We could, therefore, argue that an ethic of technology is needed that does not allow its abusive use and makes it responsible for all parties involved.

We can conclude that such ethics already exists, named Technoetics.

\section{References}

Bunge, M. (1975). Towards a Technoethics, Philosophic Exchange. Article 3, $6(1)$

Capcelea, V. (2014). Atributia tehnoeticii la solutionarea problemelor morale cu privire la raportul dintre om, tebnică și tehnologiile create de umanitate. Available at: http://dspace.usarb.md:8080/xmlui/handle/123456789/2171. Accesat 16.02.2017

Ellul, J. (1964). The Tehnological Society, traducere de Robert K. Merton, Vintage Books, New York: A Division of Random House

Ellul, J. (1980). The Power of Technique and The Ethics of Non-Power, Myths of Information: Technology and Postindustrial Culture. pp. 242-247 Jonas, H. (1979), Toward a Philosophy of Technology, Hastings Center Report, Vol. 9. pp. 34-43

Keulartz, J., Schermer, M, Korthals, M., Swierstra, T. (2004). Ethics in Technological Culture: A Programmatic Proposal for a Pragmatist Approach, Science, Technology, \& Human Values, Vol. 29(1). pp. 329

Luppicini, R. (2009), The Emerging Field of Technoethics, Canada: Handbook of Research on Technoethice. Vol 2

Luppicini, R. (2010). Technoethics and the evolving knowledge society. Hershey: Idea Group Publishing. Available at: http://research.omicsgroup.org/index.php/Technoethics

Marx, K. (1856). Cuvântare rostită la aniversarea gazetei. The people's paper. Londra. Cuvântare din cartea Despre rolul industriei in dezvoltarea societății. București: Editura Politică (1965). pp. 36-38

Mitcham, C. (2005), Encyclopedia of Science, Technology, and Ethics, Detroit: Macmillan Reference USA, Vol. 4. p. 11

Popoveniuc, B. (2016), Filosofia Singularitătiii. Creierul Global o etică a gândirii fără om, București: Editura EIKON

Schuurman, E. (2010), Responsible Ethics for Global Technology, Axiomathes, 20. pp. $107-127$

Spengler, O. (1966). Omul și filosofia vieții. Oradea: Editura Aion 
Stiegler B. (1998). Technics and Time: The fault of Epimetheus, Stanford University Press

Toffler, A. \& Toffler, H. (1995). A crea o nonă civilizatie, traducere din limba engleză de Mihnea Columbeanu. Oradea: Editura ANTET

Toffler, A. (1973). Şocul V iitorului. Bucureşti: Editura Politică

Toffler, A. (1983). AL Treilea Val. Bucureşti: Editura Politică. Available at: http://research.omicsgroup.org/index.php/Technoethics. Accesat la data de 19.09.2017. 